\author{
진공관형 태양열 집열장치의 성능평가 및 해석 연구 \\ 전태규 - 안영철 ${ }^{* \dagger}$ \\ 부산대학교 건축공학과 대학원, ${ }^{*}$ 부산대학교 건축공학과 \\ (2012년 1월 18일 접수, 2013년 6월 5일 수정, 2013년 6월 5일 채택)
}

\title{
Study on Analysis and Evaluation of Performance for Evacuated Tubular Solar Collector System
}

\author{
Tae-Kyu Chun $\cdot$ Young-Chull $\mathrm{Ahn}^{*}{ }^{*}$ \\ Graduate School of Architectural Engineering, Pusan National University, \\ *Dept. of Architectural Engineering, Pusan National University \\ (Received 18 January 2012, Revised 5 June 2013, Accepted 5 June 2013) \\ 요 약

\begin{abstract}
태양열 에너지는 우리나라의 전체 에너지에서 차지하는 비율은 아직 미미하지만, 근래 이 분야에 대한 연구가 활발히 이루어지고 있다. 본 연구는 외부 날씨의 영향을 받지 않고 실내에서 안정적으로 태양열집열기에 관한 실험을 수행할 수 있는 태양열집열기 성능검사 시스템을 구축하고 새로운 형태의 태양열집열기를 연구·개발하기 위한 기초자료를 얻는데 있다. 이를 위해 태양열집열기 성능검사 시스 템에 대한 CATIA 설계 및 제작을 거쳐 성능검사를 실시하였으며, 본 시스템에 장착된 이중진공관 집열기에 대한 수치해석을 수행하였다. 실험 결과 태양열집열기 성능검사 시스템의 설정온도차 $(\Delta \mathrm{T})$ 의 증가에 따라 작동회수는 감소하지만 총 작동시간은 모든 경우에 거의 동일함을 알 수 있었다. 또한 수치해석 결과 태양열흡수부의 온도가 높을수록 집열기 중심에서의 온도 감소율이 증가하는 것을 알 수 있었다.
\end{abstract}

주요어 : 신재생에너지, 태양열에너지, 태양열집열기, 성능검사시스템, 태양열수치해석

\begin{abstract}
The thermal performance for test system with evacuated tubular solar collector is experimentally investigated to obtain the basis data for developing new type solar collector. For this purpose, the test system was designed using CATIA and then after being manufactured, the system was tested using evacuated tubular solar collector. Numerical analysis, furthermore, was performed using ANSYS Fluent V.13 for glass evacuated tubular solar collector. The results showed that as setting temperature difference $(\Delta \mathrm{T})$ of system was increased, total operating(working) time was almost same in all cases, even though operating count was decreased. The results of numerical analysis showed that as temperature of solar absorber in glass evacuated tubular solar collector was high, the drop-rate of temperature of center part was increased.
\end{abstract}

Key words : Renewable energy, Solar heat energy, Solar collector, System of performance test, Numerical analysis of solar heat

\footnotetext{
${ }^{\dagger}$ To whom corresponding should be addressed.

Dept. of Architectural Engineering, Pusan National University,

2, Busandaehak-ro, 63beon-gil, Geumjeong-gu, Busan 609-735,

Korea

Tel : 051-510-2492 E-mai : ycahn@pusan.ac.kr
} 


\section{1. 서 론}

석탄, 석유, 천연가스와 같은 화석연료는 지구온난 화 문제를 야기 시키고 매장량에도 한계가 있기 때문 에 최근 정부의 시책과 함께 신재생에너지에 관한 연 구가 활발히 이루어지고 있다[1,2]. 특히 태양열 이용 분야는 태양광 분야와 함께 신재생에너지 분야의 핵 심 중 하나이다. 그러나 친환경 저탄소 배출에너지로 서의 신재생에너지 분야에 관한 연구가 활발히 이루 어지고 있음에도 불구하고 이 분야가 전체 에너지 사 용량 중에 차지하는 비율은 현재 약 $2 \%$ 에 불과하다 [3]. 태양열에 관한 연구는 윅(wick)의 형상[4,5], 비 유리식 집열기[6], 태양열집열기의 구리-유리 접합기 술[7], 태양열집열기의 히트파이프[8]에 관한 연구 등 이 있으나 태양열집열기의 열성능[9-11]에 관한 연구 가 가장 활발히 이루어지고 있다. 태양열 집열기 부 분에서 중국이 세계시장의 대부분을 차지하고 있으며 또한 많은 특허를 보유하고 있는 것으로 알려지고 있 다[12]. 따라서 우리나라도 태양열 집열부분에 대해, 외국제품의 특허 회피 전략과 더블어 새로운 집열분 야에 대한 집중적인 투자와 연구가 더 활발히 이루어 져야 할 것이다.

본 연구의 목적은 실내연구가 가능하도록 인공태 양으로서 할로겐램프를 이용하여 새로운 형태의 태양 열집열기(solar collector)의 성능을 보다 간편하고 효 율적으로 검사할 수 있는 태양열집열기 성능검사 시 스템을 구축하고 또한 새로운 형태의 태양열집열기를 연구·개발하기 위한 기초자료를 얻는 것이다. 이를 위해 태양열집열기 성능검사 시스템에 대한 3D

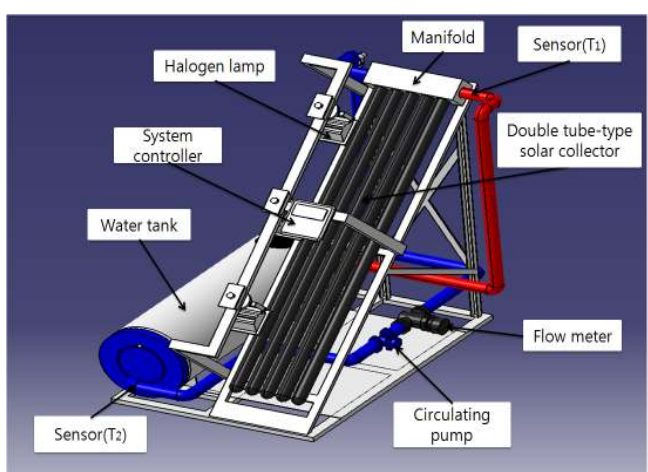

Fig. 1. CATIA modeling of system for performance test.
CATIA 설계 및 제작을 수행하였으며 이중진공관 태 양열집열기를 이용하여 성능검사를 실시하였다. 또한 본 연구의 최종 목적인 새로운 형태의 태양열집열기 를 연구·개발하기 위한 기초자료를 얻기 위하여 본 연구에서 구축한 태양열집열 장치에서 작동되는 이중 진공관 태양열집열기의 특성파악 및 수치해석을 수행 하였다.

\section{2. 실험장치 및 실험방법}

새로운 형태의 태양열집열기의 연구 및 개발에 사 용될 수 있는 태양열집열기 성능검사 시스템에 대한 3D CATIA 설계 형상을 Fig. 1에 나타내었다. 이 장 치는 인공태양인 할로겐램프(DIMMER, 소비전력 Min. $0 \mathrm{~W} \sim \mathrm{Max} .1 \mathrm{~kW}), 5$ 개의 이중진공관형 태양열집 열기, 매니폴드, 유량계(KS B 5336, SSW, 0.5 $5 \mathrm{~m} 3 / \mathrm{h})$, 순환펌프 $(\mathrm{PH}-045 \mathrm{M}, 35 \mathrm{liter} / \mathrm{min})$, 물저장조 (용적 146L), 시스템 컨트롤러(SR 868C8), 2개의 센 서, 각종 배관장치 등으로 구성되어져 있다. 실험 시 에는 실내의 형광등을 모두 소등 시킨 후 빛의 밝기 를 조절할 수 있는 할로겐램프를 상, 중, 하로 구분하 여 열을 가하였다. 할로겐램프에 노출된 이중진공관 내부의 온도가 상승하여 히트파이프를 통하여 그 열 이 매니폴드에서 열교환이 일어난다. 순환폄프에 의 해 저장조의 물은 매니폴드에서 열교환이 일어나 고 온이 되며(센서 $\mathrm{T} 1$ 에서 검출) 배관을 통해 물저장조 로 유입된다. 이 고온의 유입되어진 물을 생활용수 및 난방용으로 사용하게 되며, 사용 후(실험 장치에 서는 일정 시간 경과 후) 저온이 된 물은 물저장조의

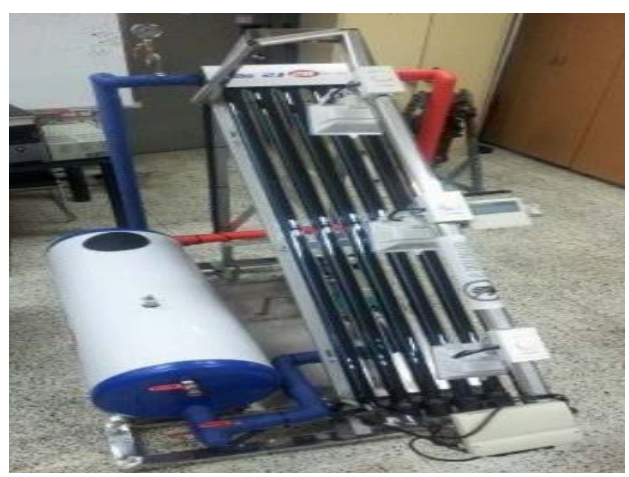

Fig. 2. Photograph of system for performance test.

Journal of Energy Engineering, Vol. 22, No. 2 (2013) 


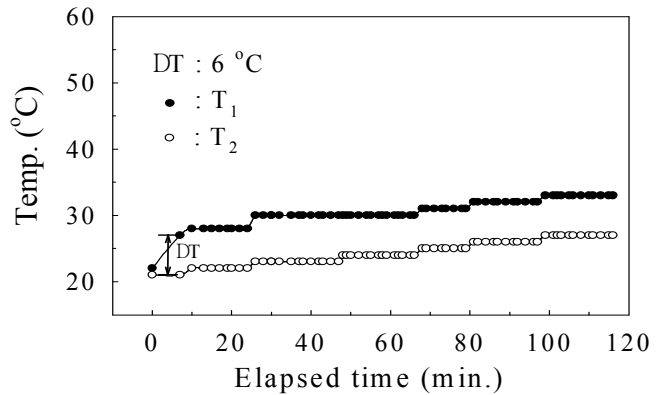

Fig. 3. (a) Temperature variation with respect to elapsed time $\left(\Delta \mathrm{T}=6^{\circ} \mathrm{C}\right)$.

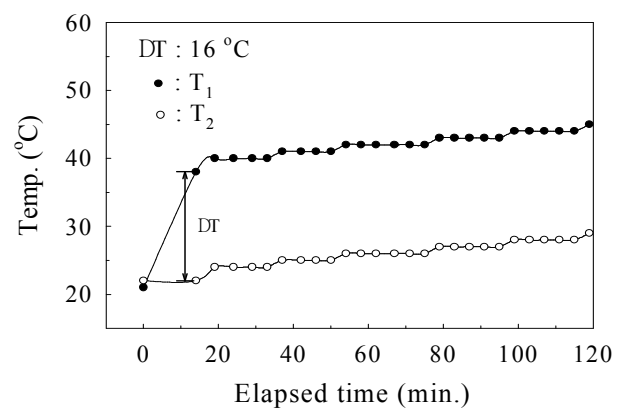

Fig. 3. (c) Temperature variation with respect to elapsed time $\left(\Delta \mathrm{T}=16^{\circ} \mathrm{C}\right)$.

배출구(센서 $\mathrm{T} 2$ 에서 검출)를 통해 펌프와 유량계를 지나 매니폴드로 향하게 된다. 본 실험장치에서는 센 서 $\mathrm{T} 1$ 과 센서 $\mathrm{T} 2$ 의 설정온도차 $(\Delta \mathrm{T})$ 를 시스템 컨트롤 러에서 조절하며 이를 통해 물의 사용온도를 설정할 수 있도록 하였다. CATIA 설계를 토대로 제작한 태 양열집열기 성능검사 시스템을 Fig. 2에 나타내었다.

\section{3. 실험결과 및 고찰}

\section{1 태양열집열기 성능검사 시스템의 평가}

Fig. 3(a) Fig. 3(d)에 매니폴드에서 검출되는 고 온의 온도(T1)와 물저장조의 배출구에서 검출되는 저 온의 온도(T2)의 설정온도차 $(\Delta \mathrm{T})$ 가 각각 $6,11,16$, $20^{\circ} \mathrm{C}$ 일 때의 변화를 나타내었다. 여기서는 새로운 형 태의 태양열집열기를 연구·개발하기 위한 기초자료를 얻기 위하여 설계 및 제작한 태양열집열기 시스템에 대한 성능 평가를 수행하고자 하였으며 태양열집열기 로서 이중진공관식 태양열집열기를 장착하여 실험을

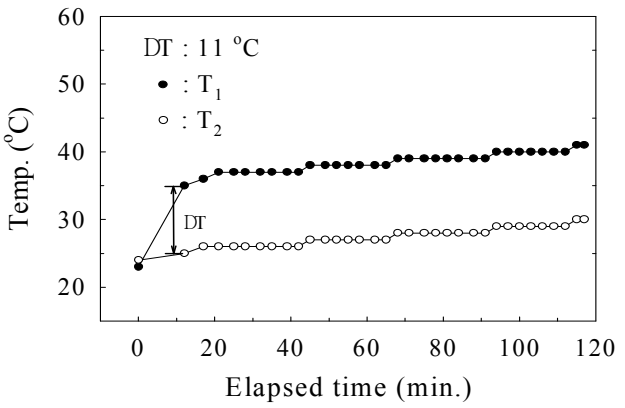

Fig. 3. (b) Temperature variation with respect to elapsed time $\left(\Delta \mathrm{T}=11^{\circ} \mathrm{C}\right)$.

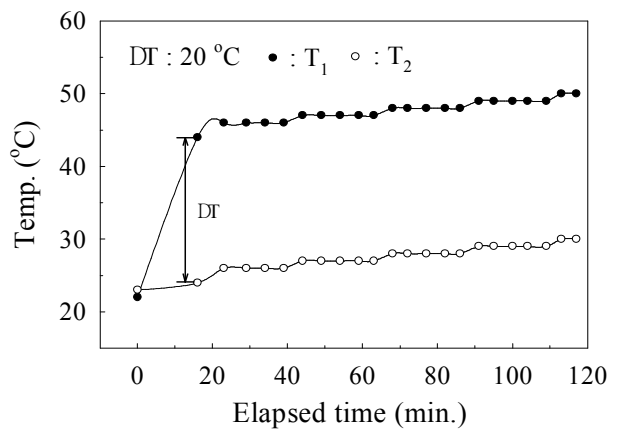

Fig. 3. (d) Temperature variation with respect to elapsed time $\left(\Delta \mathrm{T}=20^{\circ} \mathrm{C}\right)$.

수행하였다. 여기서 취득한 데이터는 향후 연구.개발 할 새로운 형태의 태양열집열기와의 비교 자료로써 사용되어질 것이다. 그림에서 관측되어지는 바와 같 이, 각각 설정한 온도차 $(\Delta \mathrm{T}) 6,11,16,20^{\circ} \mathrm{C}$ 는 최초 의 첫 시스템 작동과 함께 실현되어지는 것을 알 수 있다. 즉 Fig. 3(a)에서 설정온도차 $(\Delta \mathrm{T})$ 는 항상 $6^{\circ} \mathrm{C}$ 를 유지하며 Fig. 3(b) Fig. 3(d)에서도 각각 설정한 온 도차 $(\Delta \mathrm{T})$ 인 $11,16,20^{\circ} \mathrm{C}$ 를 2 시간의 측정동안 항상 유지되는 것을 확인할 수 있다. 인공태양인 할로겐램 프의 빛 조절을 모두 동일하게 하였으므로 태양열집 열기가 받아들이는 열은 항상 일정하다. 여기서 설정 온도차 $(\Delta \mathrm{T})$ 를 증가시킴에 따라 매니폴드에서의 고온 의 온도(T1)와 물저장조의 저온의 온도(T2)는 함께 증가한다. 또한 그림에서 알 수 있는 바와 같이 설정 온도차가 증가할수록 취득되어지는 데이터 개수가 감 소한다. 이 이유들에 대해서는 후술하기로 한다. 결과 적으로 설정온도차를 크게 하여야 고온의 온수를 많 이 얻을 수 있다는 것을 실험을 통해 확인할 수 있다. 


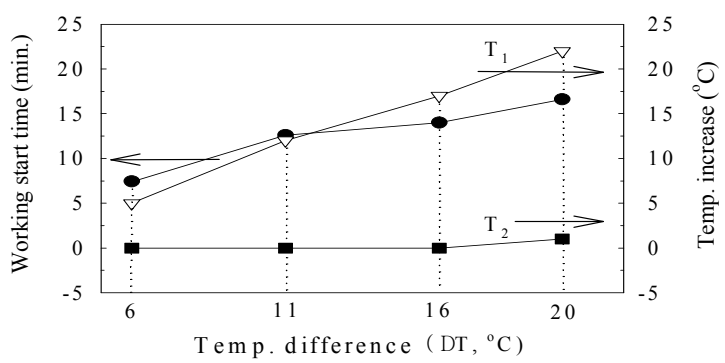

Fig. 4. Working start time and temperature increase with respect to temperature difference $(\Delta \mathrm{T})$, respectively.

본 실험에서 약 2 시간의 측정동안 온도는 계속적으로 증가한다. 따라서 실제 제품에 적용할 때에는 온수가 어느 일정온도까지 상승하면 작동을 멈추게 하는 장 치가 필요할 것으로 판단된다. 또한 Fig. 3(d)에서 알 수 있는 바와 같이 본 장치의 매니폴더에서 최고온도 는 약 $50^{\circ} \mathrm{C}$, 물저장조에서 최고온도는 약 $30^{\circ} \mathrm{C}$ 이다. 생활온수로 사용되는 물저장조의 온도가 약 $30^{\circ} \mathrm{C}$ 로 써 다소 낮은 온도이지만 할로겐램프 또는 태양열집 열기 개수의 증가로 온도를 높일 수 있다. 따라서 새 로운 형태의 태양열집열기의 집열효율을 기존 제품과 서로 비교하는 데는 문제가 없을 것으로 판단된다.

Fig. 4에 Fig. 3 에서의 온도차 $(\Delta \mathrm{T})$ 을 설정하였을 때 태양열집열기 성능검사 시스템의 운전시작시간(좌 측)과 이때의 온도 $\mathrm{T} 1, \mathrm{~T} 2$ 의 온도 증가량(우측)을 나타내었다. 순환펌프의 작동이 정지상태에서 작동되 기 시작하는 동안, 즉 운전 간격의 시간에 따른 2 곳 의 온도(T1, T2)를 측정하였다. 온도차가 $6^{\circ} \mathrm{C}$ 일때는 작동하는데 7.4 분, $11^{\circ} \mathrm{C}$ 일때는 12.6 분, $16^{\circ} \mathrm{C}$ 일때는 14.0 분, $20^{\circ} \mathrm{C}$ 일때는 16.6 분의 시간이 소요되었다. 즉 태양열집열기에 저장되어지는 열의 양이 많아지기 때 문에 온도차 $(\Delta \mathrm{T})$ 가 클수록 작동하는데 많은 시간이 걸린다는 것을 의미한다. 그림 좌측의 온도 증가량에 서 관측되어지는 바와 같이, 설정온도차 $(\Delta \mathrm{T})$ 가 증가 할수록 $\mathrm{T} 1$ 의 온도는 선형적으로 증가하나 $\mathrm{T} 2$ 의 온도 는 거의 일정하다. $\mathrm{T} 1$ 의 온도 증가량은 설정온도차 $(\Delta$ T) 가 $6^{\circ} \mathrm{C}$ 일때는 $5^{\circ} \mathrm{C}, 11^{\circ} \mathrm{C}$ 일 때는 $12^{\circ} \mathrm{C}, 16^{\circ} \mathrm{C}$ 일때는 $17^{\circ} \mathrm{C}, 20^{\circ} \mathrm{C}$ 일때는 $22^{\circ} \mathrm{C}$ 으로 거의 선형적으로 변화한 다. 이것으로서 본 태양열집열기 성능검사 시스템에 서 설정온도차 $(\Delta \mathrm{T})$ 의 설정에 따라 매니폴더의 온도

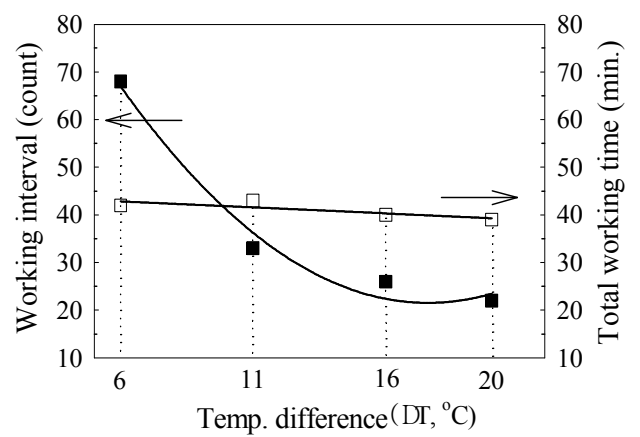

Fig. 5. Working interval and total working time with respect to temperature difference $(\triangle T)$, respectively.

변화를 예측할 수 있을 것으로 판단된다.

Fig. 5 에 온도차 $(\Delta \mathrm{T})$ 의 설정에 따라 2 시간동안 본 시스템의 작동회수(좌측)와 총 운전시간(우측)을 나 타내었다. Fig. 3에 전술한 바와 같이 설정온도차 $(\Delta \mathrm{T})$ 가 증가할수록 운전회수는 감소하는 것을 Fig. 5 에서 확인할 수 있다. Fig. 5 에서 설정온도차 $(\Delta \mathrm{T})$ 의 증가 에 따라 작동 회수는 감소하지만, 총 작동시간은 모 든 경우에 거의 동일하다. 즉 설정온도차 $(\Delta \mathrm{T})$ 를 크게 하면 작동되어지는 회수를 줄일 수 있지만 작동의 지 속시간이 길어지는 것을 의미한다. 따라서 태양열 집 열장치의 운전 시에 이를 고려할 필요가 있는 것으로 판단된다.

이중진공관 태양열집열기 내에 히트파이프(heat pipe)가 삽입되어져 있으며, 히트파이프는 이중진공 관이 태양으로부터 흡수한 열로써 히트파이프내 작동 유체의 상변화를 이용하여 매니폴더에서 냉수와 열교 환을 일으켜 온수를 생산하게 된다. 이 히트파이프 표면에 T-type의 열전대(thermocouple)를 부착하고 데이터로거(data logger, GL220 820APS)를 이용하 여 온도측정을 수행하였다. 본 장치에서 히트파이프 의 전 길이는 약 $1700 \mathrm{~mm}$ 이며 온도측정 위치를 Fig. 6 에 나타내었다. 히트파이프의 몸체 부분을 균등하게 5 등분 하여 하단부 측정위치부터 $\mathrm{A}, \mathrm{B}, \mathrm{C}, \mathrm{D}, \mathrm{E}$ 지 점으로 정하였다. 설정온도차 $(\Delta \mathrm{T})$ 가 $6^{\circ} \mathrm{C}$ 인 경우, 1 시 간 동안의 온도측정 결과를 Fig. 7에 나타내었다. 그 림에서 관측되는 바와 같이 시간의 증가에 따라 히트 파이프의 모든 부분의 온도도 증가한다. 그러나 히트 파이프의 몸체 중·하단부(B 점)에서 가장 높은 온도이 고 중간부(C점)에서 그 다음의 높은 온도를 보인다. 


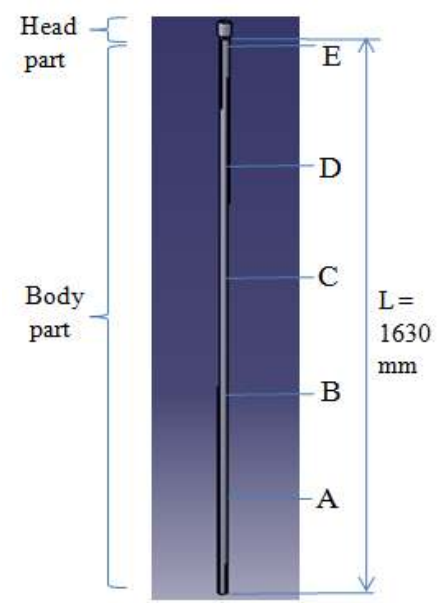

Fig. 6. Modeling of heat pipe in solar collector and position of temperature measurement.

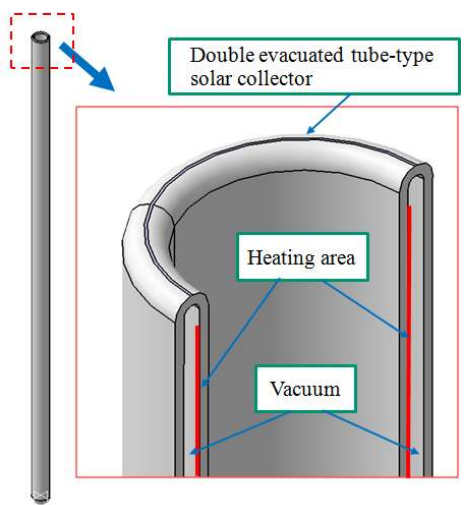

Fig. 8. CATIA modeling of solar collector with double evacuated tube-type.

즉 히트파이프의 중간부에서 하단부 사이에서 높은 온도를 보이는 것으로부터 이 부분에서 열의 흡수가 가장 많이 일어나는 것으로 예측되며 새로운 태양열 집열기의 설계시 고려해야 할 것으로 판단된다. 히트 파이프의 상단부(E점)에서 다른 지점보다 가장 낮은 온도를 보인다. 이것은 매니폴더 부분과 가장 가깝기 때문에 냉수와의 열교환에 의해 열을 방출하기 때문 인 것으로 판단된다. 새로운 태양열집열기의 최적설 계를 위해서는 히트파이프의 열흡수부와 방열부의 길 이 비율, 윅(wick)의 구조, 열전도율이 좋은 히프파이 프 내의 휘발성 물질, 방열부의 구조, 유지·보수의 용 이성 등이 고려되어야 하는 것으로 판단된다.

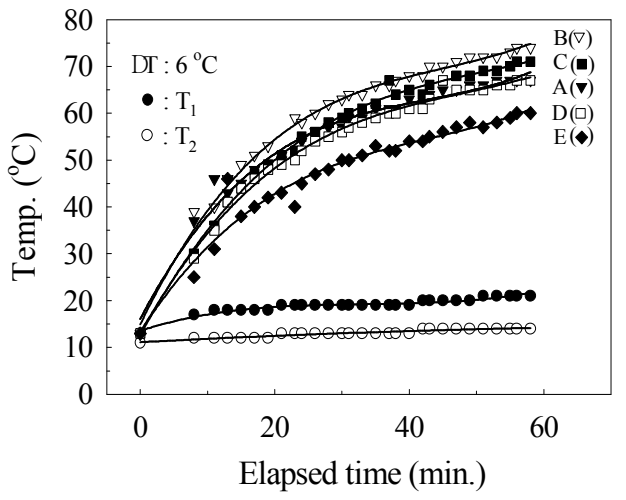

Fig. 7. Temperature of heat pipe with respect to elapsed time.

3.2 이중진공관형 태양열집열기의 수치해석

이중진공관 태양열집열기에서 태양열 흡수부인 이 중진공관 내 코팅처리부에 여러 온도가 가해질 때 그 주위의 온도변화와 공기유동에 대해 열유동 해석프로 그램인 ANSYS Fluent V.13을 이용하여 조사하였다. 계산의 편의성을 위하여 유리관 전체를 모델링하지 않고 중심축을 기준으로 한 단면만을 모델링하였다. 이렇게 함으로써 축대칭(axisymmetry) 조건을 적용 할 수 있으며 이 조건은 해석의 정확도와 편리성 및 계산시간을 줄일 수 있다. 또한 점성모델로서 유리관 주위의 공기 흐름이 크지 않기 때문에 층류를 적용하 였다. Fig. 8에 유리관으로 구성된 이중진공관의 형상 과 확대된 상층부를 나타내었다. 진공관의 내측 표면 (유리관 안쪽 벽면)에 태양열을 흡수하는 코팅부가 위치하게 되며 여기서 흡수한 열이 진공관 중앙에 있 는 히트파이프를 가열하게 된다. Fig. 8에서 집열기의 상부 및 하부는 대기압조건이고 주위온도는 $25^{\circ} \mathrm{C}$ 로 하였다. 유리관 안쪽 벽면의 가열부분(heating area) 의 온도가 $100,300,500,700^{\circ} \mathrm{C}$ 일 때의 유리관 단면, 즉 히트파이프가 위치하는 곳에서의 온도분포와 공기 의 속도분포를 조사하였다.

Fig. 9에 유리관 상부 및 하부 주위에 생성시킨 격 자(mesh)를 나타내었다. 유리관 하부의 곡면부분과 상부에 많은 격자를 생성시켰으며 총 격자수는 48,252 개로 하였다. Fig. 10 은 전체 유리관에 대해 수 치해석의 결과를 나타낸 부위이다. 즉 태양열 흡수부 의 온도가 각각 $100,300,500,700^{\circ} \mathrm{C}$ 일 때, 집열기 


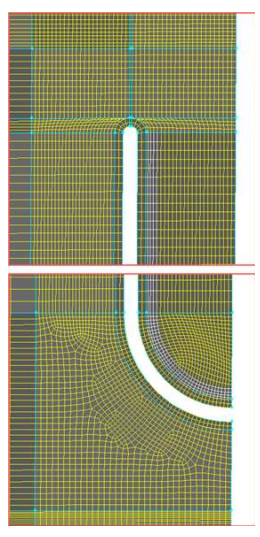

Fig. 9. Mesh.

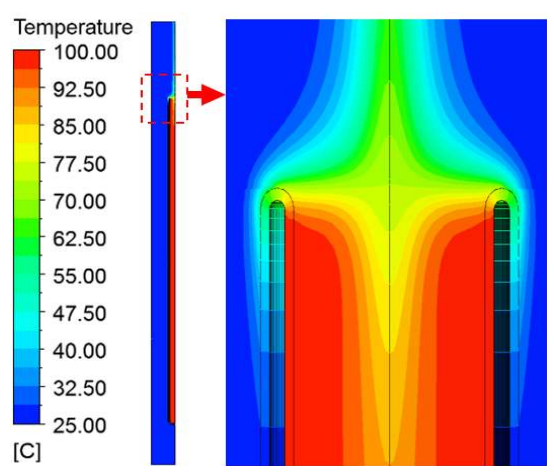

Fig. 11. (a) Temperature distribution of solar collector when temperature of heating area is $100^{\circ} \mathrm{C}$ (upper part).

길이방향의 $\mathrm{A}, \mathrm{B}, \mathrm{C}, \mathrm{D}, \mathrm{E}$ 점의 온도와 집열기 상부 $\mathrm{E}$ 점에서 단면 $\mathrm{a}, \mathrm{b}, \mathrm{c}, \mathrm{d}, \mathrm{e}$ 점의 온도를 조사하였다. 태양열 흡수부의 온도가 $100^{\circ} \mathrm{C}$ 일 때 태양열집열기 상부 및 하부 단면에서의 온도분포를 각각 Fig. 11(a) 와 Fig. 11(b)에 나타내었다. Fig. 11(a)에 관측되어지 는 바와 같이, $100^{\circ} \mathrm{C}$ 의 태양열흡수부의 온도는 중심 부로 갈수록 떨어진다. 이것은 $25^{\circ} \mathrm{C}$ 외부대기와의 열 교환의 영향 때문인 것으로 판단되며, Fig. 11(b)와 같이 외부대기의 영향을 적게 받는 하부는 태양열흡 수부의 온도를 그대로 유지하고 있다.

Fig. 12 에 태양열흡수부의 온도가 $100^{\circ} \mathrm{C}$ 일 때 공 기유동의 속도벡터를 나타내었다. 태양열흡수부의 온 도상승에 따라 유리관 외측의 인접공기는 밀도의 증 가에 따라 상승하는 것이 관측된다. 또한 유리관 내 측의 인접공기도 유리관 벽면 근처에서 상승하다가 중심단면에서 하강하는 모습도 관측된다. 실제 태양

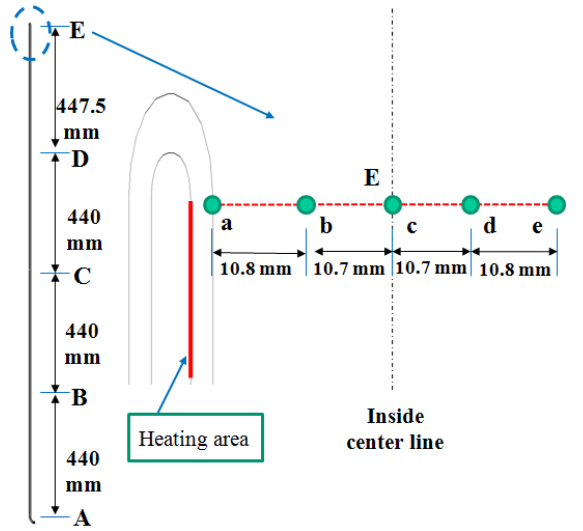

Fig. 10. Position of temperature measurement using numerical analysis.

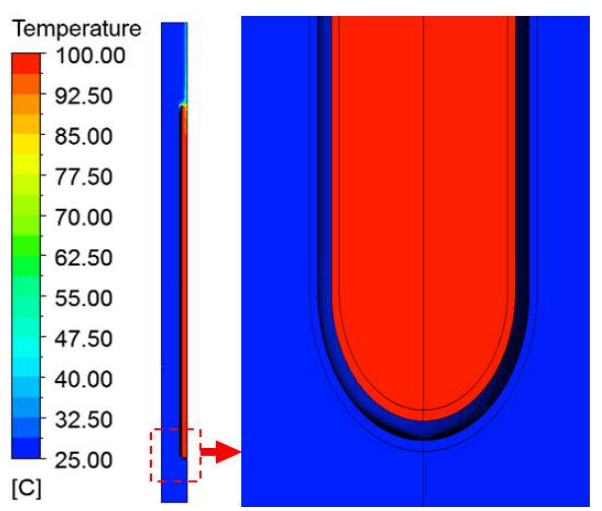

Fig. 11. (b) Temperature distribution of solar collector when temperature of heating area is $100^{\circ} \mathrm{C}$ (lower part).

열집열기에서는 유리관 내측에 히트파이프가 장착되 어 있기 때문에 유동변화에 관한 이러한 현상은 큰 의미가 없을 수 있다. 실제의 현상에 근접시키기 위 해서는 유리관의 내측에 히트파이프를 설치하여 열의 흡수부로 지정한 후 수치해석을 수행하는 것이 타당 하다. 그러나 여기서는 새로운 형태의 태양열집열기 를 설계하기 위한 기초자료로 활용하는데 가치가 있 는 것으로 판단된다.

Fig. 10 에서 나타낸 $100,300,500,700^{\circ} \mathrm{C}$ 일 때의 집열기 중심축 길이방향 $\mathrm{A}, \mathrm{B}, \mathrm{C}, \mathrm{D}, \mathrm{E}$ 점의 온도 결 과를 Fig. 13에 나타내었다. 유리관 중심축 온도는 E 점, 즉 최상부의 위치를 제외하고 모두 태양열흡수부 의 영향을 그대로 받는다는 것을 알 수 있다. E점 온 도의 감소는 외부 대기와의 영향 때문인 것은 전술한 바와 같다. 여기서 흥미로운 것은 태양열흡수부의 온 도가 높을수록 상부 $\mathrm{E}$ 점에서의 온도 하강율이 크다 


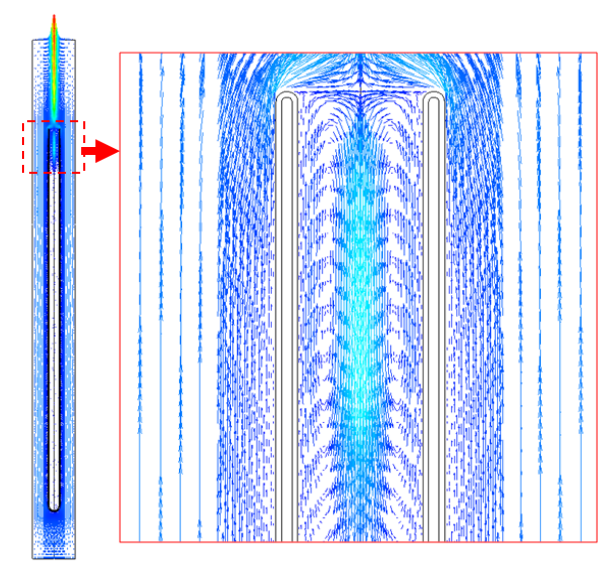

Fig. 12. Velocity vector of solar collector when temperature of heating area is $100^{\circ} \mathrm{C}$ (upper part).

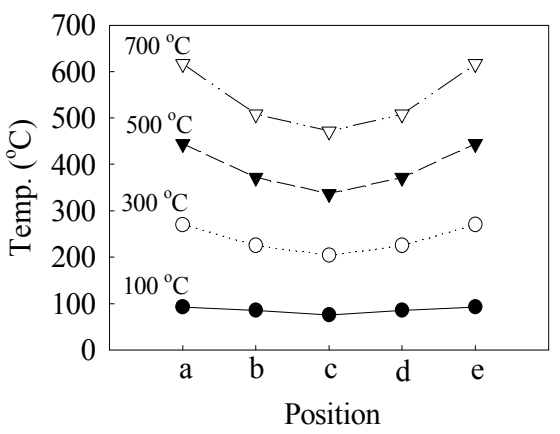

Fig. 14. Temperature distribution with respect to horizontal position in upper part.

는 것이다. 이것은 태양열흡수부의 온도가 높을수록 외부와의 열교환이 활발히 일어난다는 것을 의미하는 것으로 판단된다.

Fig. 14에 태양열흡수부의 온도가 $100,300,500$, $700^{\circ} \mathrm{C}$ 일 때의 집열기 상부 $\mathrm{E}$ 점에서 단면 $\mathrm{a}, \mathrm{b}, \mathrm{c}, \mathrm{d}$, e 점의 온도분포를 나타내었다. 태양열흡수부 표면의 온도(a와 e 점)에서 중심(c점)으로 갈수록 온도가 떨 어진다. 또한 태양열흡수부의 온도가 높을수록 단면 에서의 온도 감소율이 커지는 것을 확인할 수 있다. 여기서 수치계산상으로 태양열흡수부의 온도가 70 $0^{\circ} \mathrm{C}$ 일 때 최대 $32.7 \%$ 의 온도감소가 발생하였으며, $100{ }^{\circ} \mathrm{C}$ 일 때 최대 $24.0 \%$ 의 온도감소가 발생하였다. 이러한 결과는 개발하고자 하는 태양열집열기의 길이 와 직경의 비를 결정하는데 도움이 될 수 있을 것으 로 판단된다.

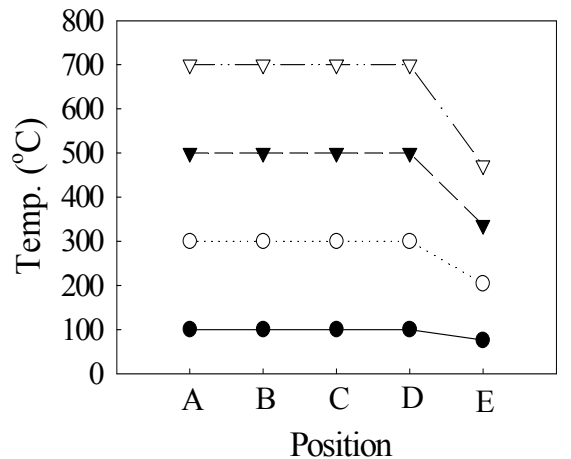

Fig. 13. Temperature distribution with respect to vertical position in centerline.

\section{4. 결 론}

개발 대상의 태양열집열기의 성능을 검사할 수 있 는 태양열집열기 성능검사 시스템을 구축하고 새로운 형태의 태양열집열기를 연구-개발하기 위한 기초자료 를 얻기 위해 실험과 수치해석을 수행하였다. 그 결 과 다음과 같은 결론을 얻었다.

1. 새로운 형태의 태양열집열기를 연구·개발하기 위해 설계 및 제작한 태양열집열기 시스템 에 대한 성능평가를 수행하였다. 그 결과 태양열 집열기 성능검사 시스템에서 온도차 $(\Delta \mathrm{T})$ 의 설정 에 따라 매니폴더의 온도변화를 예측할 수 있다.

2. 태양열집열기 성능검사 시스템에 설정온도차 $(\Delta$ $\mathrm{T}$ )의 증가에 따라 작동 회수는 감소하지만 총작 동시간은 모든 경우에 거의 동일하다.

3. 본 실험장치에 장착한 히트파이프는 중간과 하 단부 사이에서 가장 높은 온도를 보인다. 이의 결과는 새로운 태양열집열기 설계 시 고려할 필 요가 있다.

4. 수치해석 결과로부터 이중진공관 태양열흡수부 의 온도가 높을수록 중심부에서의 온도 감 소율은 증가한다. 본 수치계산에서는 태양열흡 수부의 온도가 $700^{\circ} \mathrm{C}$ 일 때 최대 $32.7 \%$ 의 온도 감소가 발생하였다. 


$$
\text { 후 기 }
$$

본 논문은 중소기업청에서 지원하는 2012년도 산 학연공동기술개발사업(No. C0038495)의 연구수행으 로 인한 결과물임을 밝힙니다.

\section{참고문헌}

1. 임홍탁, 김신, “후발국 신재생에너지 기술개발의 동력 : 한국의 신재생에너지 기술개발 사 업 사례연구”, 한국에너지공학회, Vol. 20, No. 4, pp. 267-277, 2011.

2. 전수영, 박상원, 송호준, 박진원, “원자력과 신재 생에너지 발전설비 확대에 따른 온실가스 저 감 잠재량에 관한 연구”, 한국에너지공학회, Vol. 18, No. 3, pp. 191-202, 2009.

3. 박용정, 김경훈, "수평형 지열원 히트펌프 시스 템에 관한 연구”, 한국에너지공학회, $\mathrm{Vol}$. 15, No. 3, pp. 160-165, 2006.

4. 박종찬, 이석호, 이충구, “마이크로 세라믹 윅을 사용한 루프 히트파이프의 특성 연구”, 대한 기계학회논문집 B권, $\mathrm{Vol} .31$, No. 10 , pp. 823-831, 2007.

5. 김병기, 정경택, 장환영, 서정세, “그루브형 히트 파이프를 갖는 이중진공관형 태양열집열 기 의 열전달에 관한 실험적 연구”, 대한설비공학회 하계학술대회, pp. 965-969, 2006.

6. 오승진, 현준호, 김남진, 이윤준, 천원기, “비유 리식 진공관의 진공도가 집열판의 열적 특 성에 미치는 영향", 한국태양에너지학회, Vol. 28, No. 3, pp. 67-73, 2008.

7. 김철영, 임형봉, 조남권, 곽희열, “진공관형 태양 열 집열기의 구리-유리 직접 접합 기술”, 한 국세라믹학회, Vol. 43, No. 9, pp. 544-551, 2006.

8. 정원복, 정의국, 장혁, 부준홍, 곽희열, “진공관 형 태양열 집열기용 히트파이프 개발 연 구”, 한국태양에너지학회 추계학술대회, pp. 80-85, 2005.

9. 부준홍, 정원복, 곽희열, “확관 응축부를 갖는 진공관형 태양열 집열기용 히트파이프 성능 비 교 연구”, 한국태양에너지학회, Vol. 22, No. 4, pp. 18-25, 2002.
10. 김인환, 허남수, 김만석, 이정언, "PTC와 평판 형 태양열집열기의 성능평가 비교 연구”, 한국 태양에너지학회, Vol. 30, No. 6, pp. 28-33, 2010.

11. 김용, 서태범, 강용혁, "진공관형 태양열 집열기 의 열성능 해석", 한국태양에너지학회, Vol. 23, No. 2, pp. 43-49, 2003.

12. 에너지관리공단 신재생에너지센터, "태양열", 신재생에너지 RD\&D 전략 2030 시리즈, 북스 힐, 2007. 